\title{
A STUDY ON THE IMPACT OF TOTAL QUALITY HUMAN RESOURCE
}

\section{FACTORS ON ORGANIZATIONAL ENGAGEMENT}

\section{IN RELIANCE JIO, CHENNAI}

\author{
K. SUBANIYA SARAH ${ }^{1} \&$ P. N. PRASAD ${ }^{2}$ \\ ${ }^{I}$ Research Scholar, Bharathiar University, Coimbatore, Tamil Nadu, India \\ ${ }^{2}$ Research Supervisor, Bharathiar University, Coimbatore, Tamil Nadu, India
}

\begin{abstract}
Employee engagement is one of the key factors that is needed for a dynamic industry like telecommunication in India. The attrition rate of the sector is a high post Jio impact. Hence the alternate of human resource practices, total quality human resource management variable are taken up for the study. TQHRM is the addition of TQM concepts in HRM practices. Therefore, TQHRM practices and employee engagement are key latent variables considered for the study. The present research involved an investigation on a sample of 159 employees Reliance Jio Company using questionnaires. All the data were analysed applying appropriate statistical tools by using SPSS 24.0. In our study it is found that there is a significant influence of TQHRM practices (p-value less than 0.05) on organizational engagement.
\end{abstract}

Received: Dec 27, 2018; Accepted: Jan 17, 2019; Published: Jan 18, 2019; Paper Id.: IJHRMRFEB20199

\section{INTRODUCTION}

Total Quality Management (TQM) is one of the optimized forms of management practices which provide an additional competitive advantage to many organizations to achieve their success. In TQM, all individuals of an organization are involved in improving services, process and the work environment. Many organizations are experiencing drastic transformation, targeting at improving employees skill and capacity to respond proactively and proficiently to customer requirements in terms of innovation, service, quality, speed and price. Globally, Quality Management (QM) approaches such as the ISO 9000 series of standards and TQM have been adopted, which has simplified the universal supply chains of today's business (Qui \& Tannock, 2010).

Reliance Jio, a subsidiary of Reliance Industries is LTE mobile network operator which revolutionized the Indian Telecom sector. The company provides wireless 4G LTE service network. The company has an excellent customer base, expands over 21,000 cities, towns and over 4, 00,000 villages of India. Reliance Jio Infocomm Limited launched of its digital services with Jio in Mumbai on 1st September 2016 with Jio Welcome Offer. Jio crossed 100 million subscribers by the end of February 2017. This is the fastest growth by any mobile network operator anywhere in the world. The product variants of Jio include Jio-Phone, 4G broadband, LYF smart phones, Jio-net Wi-Fi and Jio Apps. Reliance Jio reduces the attrition rate by providing 10-15\% hike to its top performers in the salaries. 


\section{OBJECTIVES OF THE STUDY}

- $\quad$ To study organizational engagement of Reliance Jio.

- To measure the effectiveness of the identified factors of Total Quality Human Resource Management practices of the organization.

- To analyse the impact of Total quality human resource factors on the organizational engagement.

- To suggest measures to enhance organizational engagement through TQHRM practices.

\section{RESEARCH METHODS}

The overall sample size for this research work is 159. Sampling location is a locality/destination IS Chennai. In this research, the respondents who are taking part in the survey are the employees of Reliance Jio. The sampling method adopted is simple random sampling. This research has followed empirical method.

Out of 159 employees of the Reliance Jio company, 51.6\% have disagreed with the statement "I am really not into the "goings-on" in this organization®" while only $40.9 \%$ of total employees have agreed to the statement "I am really not into the "goings-on" in this organization®". Around 8\% of total employees have neither agreed or disagree with this statement.

When the statement "Being a member of this organization makes me come "alive"” is concerned, $15.7 \%$ agree with the statement whereas $61 \%$ of the employees disagree. And, $23.3 \%$ of employees neither agree nor disagree with the statement. Out of 159 employees among the Reliance Jio companies, 15.7\% disagree with the statement "Being a member of this organization is exhilarating for me" whereas $62.2 \%$ agree with it. And, $22 \%$ of employees neither agree nor disagree with the statement. About, $12.6 \%$ of employees disagree with the statement "I am highly engaged in this organization" while $66.6 \%$ agree. And, there were $20.8 \%$ employees of the Reliance Jio Company neither agree nor disagree with the statement.

Table 1: Mean Organizational Engagement of Reliance Jio

\begin{tabular}{|c|c|c|l|l|l|c|}
\hline \multicolumn{2}{|c|}{} & \multicolumn{5}{|c|}{ Organizational Engagement } \\
\hline \multicolumn{2}{|c|}{ Company } & $\begin{array}{l}\text { I am really not } \\
\text { into the } \\
\text { "goings-on" in } \\
\text { this } \\
\text { organization® }\end{array}$ & $\begin{array}{l}\text { Being a } \\
\text { member of this } \\
\text { organization } \\
\text { make me come } \\
\text { "alive." }\end{array}$ & $\begin{array}{l}\text { Being a } \\
\text { member of this } \\
\text { organization is } \\
\text { exhilarating for } \\
\text { me }\end{array}$ & $\begin{array}{l}\text { I am highly } \\
\text { engaged in this } \\
\text { organization }\end{array}$ & $\begin{array}{l}\text { I am really not into } \\
\text { the "goings-on" in } \\
\text { this organization® }\end{array}$ \\
\hline \multirow{2}{*}{ Reliance } & Mean & 2.88 & 3.56 & 3.55 & 3.69 & 2.88 \\
\cline { 2 - 7 } \\
$\begin{array}{l}\text { Std. } \\
\text { Deviation }\end{array}$ & 1.366 & 1.145 & 1.145 & 1.120 & 1.366 \\
\hline
\end{tabular}

Under organizational engagement, the attribute 'I am highly engaged in this organization' has the highest mean value of 3.69 and the attribute 'I am really not into the "goings-on" in this organization®' had the lowest mean 2.88 . Therefore, the organizational engagement is reasonably good in this study population

\section{TOTAL QUALITY HUMAN RESOURCE FACTORS}

Burli et al. (2012) and Martinez-Costa et al. (2008) explained TQM as a "systematic quality practices" for the organizational management to create a necessary modification in the performance with the aim of improving "quality, productivity, customer's satisfaction and profitability”(Burli, Kotturshettar, \& Dalmia, 2012). 
Table 2: Correlation between Organizational Engagement and TQHRM Factors

\begin{tabular}{|c|c|c|c|c|c|}
\hline & & 01 & 02 & $\mathbf{O 3}$ & 04 \\
\hline \multirow{5}{*}{ Leadership } & LD1 & $.423^{* *}$ & $.750^{* * 1}$ & $.648^{* *}$ & $.673^{* * *}$ \\
\hline & LD2 & $.419^{* * *}$ & $.576^{* * 4}$ & $.750^{* *}$ & $.602^{* * *}$ \\
\hline & LD3 & $.388^{* *}$ & $661^{* * *}$ & $.694^{* *}$ & .746 \\
\hline & LD4 & $.291^{* * *}$ & .576 & $.604^{* * *}$ & $.603^{* * *}$ \\
\hline & LD5 & $.335^{* *}$ & $.440^{* * 3}$ & $.432^{* *}$ & $.544^{* * *}$ \\
\hline \multirow{5}{*}{ Communication } & CM1 & $219^{* * *}$ & $.582^{* * *}$ & $.481^{* *}$ & $.499^{* * *}$ \\
\hline & CM2 & 0.130 & $317^{* i}$ & $.499^{* * *}$ & $.431^{* * *}$ \\
\hline & CM3 & $.374^{* * * 6}$ & 650 & $.597^{* *}$ & $.754^{* * *}$ \\
\hline & CM4 & $.369^{* * *}$ & $450^{* * *}$ & $.556^{* *}$ & $.534^{* * *}$ \\
\hline & CM5 & $.355^{* *}$ & $.5966^{* *}$ & $.510^{* *}$ & $.527^{* * *}$ \\
\hline \multirow{5}{*}{ Training } & TR1 & $.621^{* *}$ & $671^{* * 4}$ & $.568^{* * *}$ & $.633^{* *}$ \\
\hline & TR2 & $.330^{* * *}$ & $.490^{* * *}$ & $.666^{* *}$ & $.571^{* * *}$ \\
\hline & TR3 & $.360^{* * *}$ & $.568^{* *}$ & $.560^{* *}$ & $.622^{2 *}$ \\
\hline & TR4 & $.627^{* * *}$ & $.571^{* * 4}$ & $.559^{* * *}$ & $.560^{* * *}$ \\
\hline & TR5 & $.650^{* *}$ & $.634^{* * 4}$ & $.640^{* *}$ & $.615^{* *}$ \\
\hline \multirow{4}{*}{$\begin{array}{l}\text { Continuous } \\
\text { Improvement }\end{array}$} & CI1 & $.319^{* * *}$ & $.398^{* * 4}$ & $.518^{* *}$ & $.414^{* * * 4}$ \\
\hline & CI2 & $.381^{* *}$ & $.733^{* *}$ & $.606^{* *}$ & $.681^{* * 1 *}$ \\
\hline & $\mathrm{CI} 3$ & $.385^{* *}$ & $.482^{* *}$ & $.543^{* *}$ & $.505^{* *}$ \\
\hline & CI4 & $.224^{* *}$ & $.522^{* * 4}$ & $.504^{* *}$ & $.593^{* * *}$ \\
\hline \multirow{4}{*}{$\begin{array}{l}\text { Employee } \\
\text { Involvement \& } \\
\text { Satisfaction }\end{array}$} & EI1 & $.418^{* * *}$ & $766^{* * 14}$ & $.605^{* *}$ & $.704^{* * *}$ \\
\hline & EI2 & $.363^{* *}$ & $.630^{* * 4}$ & $.728^{* *}$ & $.643^{* *}$ \\
\hline & EI3 & $.456^{* *}$ & $.659^{* * 3}$ & $.677^{* *}$ & $.752^{\text {i* }}$ \\
\hline & EI4 & $.405^{* *}$ & $.516^{* *}$ & $.5066^{* * *}$ & $.571^{* * 1}$ \\
\hline \multirow{5}{*}{ Teamwork } & TW1 & $.277^{* *}$ & $.562^{* *}$ & $.436^{* *}$ & $.505^{* * *}$ \\
\hline & TW2 & $.359^{* * *}$ & $.458^{* * *}$ & $.636^{* * *}$ & $.579^{* * *}$ \\
\hline & TW3 & $.478^{* * *}$ & $.578^{* *}$ & $.587^{* * *}$ & $.682^{* * *}$ \\
\hline & TW4 & $.314^{* * *}$ & $.438^{* *}$ & $.483^{* *}$ & $.489^{* * *}$ \\
\hline & TW5 & $.421^{* *}$ & $.620^{* * 4}$ & $.571^{* * *}$ & $.610^{* * * 4}$ \\
\hline \multirow{4}{*}{$\begin{array}{l}\text { Performance } \\
\text { Management }\end{array}$} & PM1 & 0.105 & $.417^{* * i}$ & $.300^{* *}$ & $.362^{* * *}$ \\
\hline & PM2 & 0.104 & $.204^{*}$ & $.395^{* *}$ & $.302^{* * *}$ \\
\hline & PM3 & $.314^{* *}$ & $.666^{* * *}$ & $.501^{* *}$ & $.649^{* * *}$ \\
\hline & PM4 & $.521^{* *}$ & $.571^{* *}$ & $.573^{* * *}$ & $.605^{* * *}$ \\
\hline \multirow{3}{*}{$\begin{array}{l}\text { Recruitment \& } \\
\text { Selection }\end{array}$} & RM1 & $.348^{* * *}$ & $.760^{* *}$ & $.578^{* *}$ & $.666^{* * *}$ \\
\hline & RM2 & $.454^{* * *}$ & $511^{* *}$ & $.598^{* * *}$ & $.568^{* * *}$ \\
\hline & RM3 & $.255^{* * *}$ & $.483^{* *}$ & $.587^{* *}$ & .650 \\
\hline \multirow{3}{*}{$\begin{array}{l}\text { Reward And } \\
\text { Recognition }\end{array}$} & RW1 & $.282^{* *}$ & $.676^{* *}$ & $.577^{* *}$ & $.601^{* * *}$ \\
\hline & RW2 & $.529^{* * *}$ & $.555^{* *}$ & $.721^{* *}$ & $.619^{* * *}$ \\
\hline & RW3 & $.328^{* * *}$ & $.611^{* *}$ & $.568^{* * *}$ & $.619^{* * *}$ \\
\hline \multirow{5}{*}{$\begin{array}{l}\text { Employee } \\
\text { Participation }\end{array}$} & EP1 & $.323^{* *}$ & $.484^{* * *}$ & $.485^{* *}$ & $.513^{* * *}$ \\
\hline & EP2 & $.419^{* * *}$ & $.633^{* *}$ & $.512^{* * *}$ & $.549^{* * *}$ \\
\hline & EP3 & $.317^{* *}$ & $.533^{* *}$ & $.697^{* * *}$ & $.552^{* *}$ \\
\hline & EP4 & $.331^{* *}$ & $.635^{* *}$ & $.507^{* * *}$ & $.623^{* * *}$ \\
\hline & EP5 & $.272^{* * *}$ & $.478^{* *}$ & $.448^{* * *}$ & $.590^{* *}$ \\
\hline \multirow{4}{*}{$\begin{array}{l}\text { Customer } \\
\text { Service } \\
\text { Delivery }\end{array}$} & $\mathrm{CS} 1$ & $.176^{*}$ & $.500^{* * *}$ & $.280^{* * *}$ & $.407^{* * *}$ \\
\hline & CS2 & $.385^{* * *}$ & $.471^{* *}$ & $.645^{* *}$ & .520 \\
\hline & CS3 & $.554^{* * *}$ & .586 & $.597^{* *}$ & $.708^{* * *}$ \\
\hline & CS4 & 0.150 & $.351^{* * *}$ & $.298^{* * *}$ & $.497^{* *}$ \\
\hline & **. Co & ation is & ificant & $0.01 \mathrm{le}$ & -tailed \\
\hline
\end{tabular}




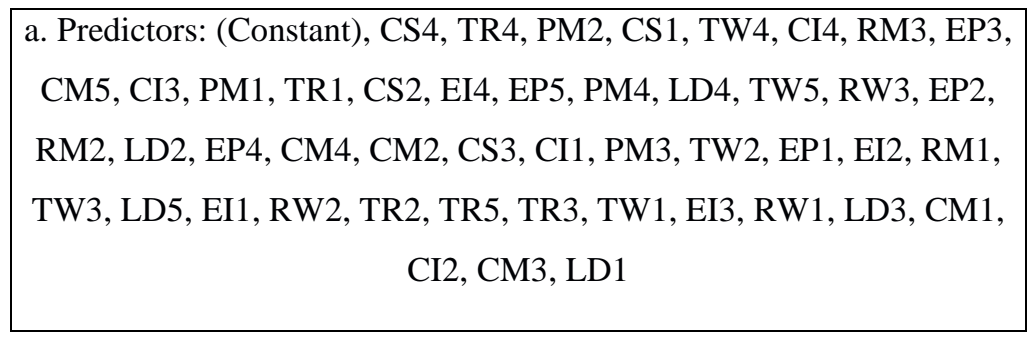

H1: There is no significant relationship between each of the TQHRM variable and organizational engagement (for each TQHRM variable)

ANOVA $^{\mathrm{a}}$

\begin{tabular}{|c|c|c|c|c|c|c|c|}
\hline & Model & $\begin{array}{l}\text { Sum of } \\
\text { Squares }\end{array}$ & Df & Mean Square & $\mathbf{F}$ & Sig. & Status \\
\hline \multirow{3}{*}{1} & Regression & 233.022 & 47 & 4.958 & 8.918 & $.000^{b}$ & \multirow{4}{*}{$\begin{array}{l}\text { Null } \\
\text { hypothesis } \\
\text { rejected }\end{array}$} \\
\hline & Residual & 61.707 & 111 & .556 & & & \\
\hline & Total & 294.730 & 158 & & & & \\
\hline \multicolumn{7}{|c|}{ a. Dependent Variable: $\mathrm{O} 1$} & \\
\hline \multicolumn{7}{|c|}{$\begin{array}{l}\text { b. Predictors: (Constant), CS4, TR4, PM2, CS1, TW4, CI4, RM3, EP3, CM5, CI3, } \\
\text { PM1, TR1, CS2, EI4, EP5, PM4, LD4, TW5, RW3, EP2, RM2, LD2, EP4, CM4, } \\
\text { CM2, CS3, CI1, PM3, TW2, EP1, EI2, RM1, TW3, LD5, EI1, RW2, TR2, TR5, } \\
\text { TR3, TW1, EI3, RW1, LD3, CM1, CI2, CM3, LD1 }\end{array}$} & \\
\hline
\end{tabular}

Under organizational engagement, the attribute 'I am highly engaged in this organization' has the highest mean value of 3.69 and the attribute 'I am really not into the "goings-on” in this organization®' had the lowest mean 2.88 . Therefore, the organizational engagement is reasonably good in this study population. This study had tested a hypothesis where the TQHRM factors were significantly influenced on the dimensions of the organizational engagements.

The significant results of this exploration are: TQHRM practices significantly associated with organizational engagement.

\section{LIMITATIONS AND DIRECTIONS FOR FUTURE RESEARCH}

Limitations of this study were; information used to test the hypotheses and different models were gathered only from one telecommunication organization from Chennai, India. Therefore, the generalization is limited and confined. Primary data were depended on employee's perceptions and viewpoints about various factors of TQHRM. Anyway these constraints and limitations in the study leave future ground for research and investigation regarding this topic.

\section{DISCUSSION}

Since, employee's engagement towards an organization will generate significant value to any type of organization. Therefore, it is inevitable for administration to analyse the effects of application of TQHRM practices on employee engagement. The present research model will help the administration to categorize which factors of TQHRM practices that have more influence on employee engagement.

The present study proposes models to analyse the impact of different TQHRM practices like leadership, training, employee's participation, extent of employee involvement, teamwork reward and recognition in increasing the different dimensions of engagement among the employees. Previously preliminary effort had been done to explore the relationship between TQHRM practices and employee engagement. 


\section{CONCLUSIONS}

It has been identified that through total quality human resource management practices the engagement levels of the individual employees can be enhanced. Thus empowerment of employees through leadership, training, teamwork and rewards and recognition will contribute to the engagement levels in a better way. The traditional HR practices can be incorporated with TQHRM practises for better results of the individual employee and the organization.

\section{REFERENCES}

1. Penang.Osland, O. (1997), "Impact of total quality attitude management and training, and work context on attitude supervisor", International Journal of Organization Analysis, Vol. 5 No. 3, pp. 291-301.

2. Powell, T.C. (1995), "Total quality management as comprehensive: a review and empirical study", Strategic Management Journal, Vol. 16 No. 1, pp. 15-27.

3. Ross, J. (1993), Total Quality Management: Text, Cases, and Readings, St Lucie Press, DelrayBeach, FL.

4. Weiss, D.J., Darwis, R.V., England, G.W. and Lofquist, L.H. (1967), Manual for the Minnesota Satisfaction Questionnaire, Minnesota Studies in Vocational Rehabilitation, University of Minnesota Industrial Relation Center, Minneapolis,

5. MN.Wilkinson, A. (1998), “Empowerment: theory and practice”, Personnel Review, Vol. 27 No. 1, p. 40

6. Zeitz, G., Johannesson, R. and Ritchie, J.E. Jr (1997), "An employee survey measuring total quality management practices and culture: development and validation”, Group and Organization Studies, Vol. 22 No. 4, pp. 414-44. 
